\title{
DESTINATION BRANDING LEMBAH HARAU SEBAGAI KAWASAN EKOWISATA
}

\author{
Rini Amadia \\ Fakultas Teknologi Informasi, Institut Teknologi Batam, \\ Jl. Gajah Mada Kompleks Vitka City, Tiban Ayu - Sekupang - Batam \\ Email: rini.amadia12@gmail.com
}

\begin{abstract}
Abstrak
Lembah Harau merupakan kawasan pelestarian alam yang terdiri dari wilayah cagar alam, objek wisata alam, dan taman wisata alam. Sebagai kawasan pelestarian alam, Lembah Harau perlu menjaga keseimbangan alam dan lingkungan. Ekowisata merupakan konsep wisata berbasis lingkungan dan alam sesuai dengan prinsip kawasan pelestarian alam. Image wilayah Lembah Harau sebagai kawasan ekowisata dibentuk dengan melakukan perancangan Destination Branding. Destination Branding merupakan strategi dari suatu destinasi wisata untuk membuat positioning yang kuat di benak wisatawan terhadap objek wisata tersebut. Perancangan Destination Branding Lembah Harau sebagai kawasan ekowisata diharapkan mampu memperkenalkan image objek wisata yang memiliki tanggung jawab terhadap lingkungan dan alam.
\end{abstract}

Kata kunci : Lembah Harau, objek wisata, destination branding, ekowisata

\begin{abstract}
Harau Valley is a natural conservation area consisting of nature reserves, natural attractions, and nature parks. As a conservation area, the Harau Valley needs to maintain the balance of nature and environment. Ecotourism is a concept of environment-based tourism and nature in accordance with the principle of nature conservation area. Image Harau Valley area as an eco-tourism area was formed by designing Destination Branding. Destination Branding is a strategy of a tourist destination to create a strong positioning in the minds of tourists to the attraction. Designing Destination Branding Harau Valley as an eco-tourism area is expected to be able to introduce the image of tourism object that has responsibility for environment and nature.
\end{abstract}

Keywords : Harau Valley, tourism object, destination branding, eco-tourism

\section{PENDAHULUAN}

Wilayah Lembah Harau merupakan kawasan pelestarian alam yang memiliki cagar alam dan suaka margasatwa yang dilindungi oleh pemerintah. Tempat ini ditetapkan sebagai cagar alam sejak 10 Januari 1993. Berdasarkan UU No. 5 Tahun 1990 pasal 31 disebutkan bahwa di dalam kawasan pelestarian alam (Taman Nasional, Taman Hutan Raya dan Taman Wisata Alam) dapat dilakukan kegiatan untuk kepentingan penelitian, ilmu pengetahuan, pendidikan, menunjang budidaya, budaya dan wisata. Namun, wilayah Lembah Harau saat ini lebih terfokus pada kegiatan objek wisatanya dibandingkan dengan kegiatan penelitian, pengetahuan, pendidikan, budidaya, budaya, serta sosial masyarakat.

Menurut BPS Lima Puluh Kota (2015:402), Lembah Harau merupakan wilayah dengan pendapatan daerah tertinggi di sektor pariwisata Kabupaten Lima puluh Kota. Bentuk wisata massal telah dikembangkan oleh pemerintah daerah 
setempat. Wisata tersebut telah berkembang cukup baik dengan pembangunan sarana dan prasarana yang dilakukan pemerintah di wilayah Lembah Harau. Namun, kegiatan wisata yang dilakukan terbatas pada berpiknik, berenang, dan berkemah. Konsep ekowisata dapat menjadi alternatif bentuk wisata yang baik sesuai dengan potensi yang dimiliki oleh Lembah Harau.

Menurut Damanik (2006: 37), ekowisata merupakan salah satu bentuk kegiatan wisata khusus dan sering diposisikan sebagai lawan dari wisata massal. Damanik mengartikan ekowisata merupakan kegiatan wisata yang menaruh perhatian besar terhadap kelestarian sumberdaya pariwisata. Ekowisata sebagai perencanaan pariwisata yang ramah terhadap lingkungan dan masyarakat. Sehingga ekowisata dapat diartikan sebagai bentuk industri pariwisata berbasis lingkungan yang tidak berdampak pada kerusakan alam dan budaya lokal serta mampu memberikan peluang kerja dan pendapatkan bagi kegiatan konservasil alam.

Weaver (dalam Yogi Ismet, 2011:1), mengatakan bahwa ekowisata adalah suatu bentuk wisata yang membantu perkembangan belajar berupa pengalaman dan penghargaan terhadap lingkungan ataupun sebagian komponennya di dalam konteks budaya, masyarakat, dan alam. Konsep ekowisata ini sejalan dengan UU No. 5 Tahun 1990 pasal 31 mengenai pengertian kawasan pelestarian alam yang memerlukan keseimbangan lingkungan disamping pengembangan potensi estetika yang ada seperti kawasan wisata. Konsep ekowisata dapat menjadikan fungsi wilayah Lembah Harau kembali sesuai dengan fungsi kawasan pelestarian alam yang telah ditetapkan sesuai perundang-undangan. Melalui konsep berbasis lingkungan yang melibatkan masyarakat, kepedulian masyarakat terhadap alam dan lingkungan wilayah Lembah Harau akan meningkat.
Penerapan konsep ekowisata tidak hanya ditargetkan pada masyarakat di wilayah Lembah Harau saja. Namun, wisatawan yang berkunjung ke wilayah Lembah Harau ikut andil dalam pelestarian lingkungan. Image wilayah Lembah Harau sebagai kawasan ekowisata perlu dibentuk sehingga persepsi konsep ekowisata dapat dikenal oleh wisatawan. Pembentukan image tersebut dapat dilakukan dengan perancangan Destination Branding.

\section{METODE PENELITIAN}

Perancangan Destination Branding Lembah Harau sebagai kawasan Ekowisata terdiri dari 4 (empat) bagian tahapan metode penciptaan, yaitu

\section{Metode Pengumpulan Data}

Data yang diperoleh berupa data primer dan sekunder, yaitu.

\section{Data Premier}

\section{a. Observasi}

Metode pengumpulan data secara observasi dilakukan dengan cara melakukan riset langsung ke lapangan (Wilayah Lembah Harau). Observasi dilakukan dengan cara terjun langsung ke wilayah Lembah Harau dan Dinas Pariwisata, Pemuda, dan Olah Raga. Hasil dari observasi ke wilayah Lembah Harau adalah mengengetahui kondisi keadaan alam, masyarakat, dan fasilitas wisata yang ada di Lembah Harau. Hasil dari observasi ke Dinas Pariwisata, Pemuda, dan olah Raga adalah untuk mengetahui pengelolaan wisata Lembah Harau.

\section{b. Wawancara}

Interview atau wawancara yaitu teknik pengumpulan data dengan cara mengajukan pertanyaan-pertanyaan secara langsung oleh pewawancara kepada narasumber. Hasil dari wawancara kemudian direkam dan ditulis. Data hasil wawancara selanjutnya dianalisis bersama data-data dari sumber lainnya. Wawancara dilakukan kepada pegawai dinas Pariwisata dan ketua pemuda di 
wilayah Lembah Harau. Hasil yang didapat adalah berupa bentuk tata cara pengelolaan wisata Lembah Harau yang dilakukan pemerintah dan masyarakat setempat.

\section{Data Sekunder}

a. Penelitian Pustaka berguna untuk mendapatkan referensi dari sumbersumber yang memuat informasi mengenai topik perancangan dan landasan teori yang digunakan. Data yang didapat dari penelitian pustaka disesuaikan dengan perancangan yang dilakukan. Sumber-sumber dapat berupa buku, artikel, media massa, dan literatur lain yang berkaitan dengan topik perancangan. Acuan sumber pustaka berupa penelitian dan kaya yang pengkarya gunakan adalah penelitian Yogi Ismet berjudul Konsep Pengembangan Lanskap Berbasis Ekowisata di Kawasan Taman Wisata Alam Lembah Harau, Sumatera Barat tahun 2011, Rancangan dari Imam M Ridwan berjudul Destination Branding Hutan Babakan Siliwangi tahun 2011, penelitian Novita Kanesti berjudul Pengembangan Pariwisata Alam Prioritas di Kabupaten Lima Puluh Kota tahun 2008, Iskandar Muda berjudul Stategi Pengelolaan Taman Wisata Alam Lembah Harau Kabupaten Lima Puluh Kota Provinsi Sumatera Barat.

b. Studi Dokumentasi, yaitu teknik pengumpulan data secara langsung berupa foto hasil survei lapangan untuk mendapatkan fakta yang akurat sehingga dapat dijadikan acuan ilustrasi dalam mendesain. Foto foto yang diambil adalah foto keadaan fasilitas wisata yang ada di Lembah Harau saat ini dan fotofoto keindahan alam Lembah Harau terbaru. Foto-foto ini dijadikan bahan referensi untuk penunjang perancangan.

\section{Metode Analisis Data}

Setelah melakukan metode pengumpulan data, data yang diperoleh dalam proses pengumpulan data akan dianalisis dan dikelompokkan. Penganalisisan data bertujuan untuk mengelompokkan data sesuai dengan kebutuhan sehingga data yang kurang tepat akan tersingkir. Data-data yang telah dianalisis akan memudahkan proses perancangan untuk menentukan kelebihan dan kekurangan dari Wilayah Lembah Harau sesuai fakta yang ada.

Metode analisis data yang penulis lakukan terdiri dari 2 (dua), yaitu.

\section{Metode Analisis Deskriptif}

Metode Analisis Deskriptif dilakukan berdasarkan informasi-informasi dan data yang diperoleh melalui proses pengumpulan data yaitu dokumentasi, wawancara, dan identifikasi data.

\section{Metode Analisis SWOT}

Perancangan pengembangan Destination Branding Lembah Harau sebagai Kawasan Ekowisata termasuk kategori promosi komersial, maka metode analisis yang akan dipakai adalah metode analisis SWOT (strengths, weakness, opportunities, and threats). Metode Analisis SWOT ini di perkenalkan oleh Albert Humphrey pada dasawarsa 1960-an dan 1970-an. Metode analisis ini dipilih karena dalam perancangan pengembangan wilayah Lembah Harau Kabupaten Lima Puluh Kota dengan strategi Destination Branding untuk membedakannya dengan destinasi wisata lainnya. Rincian analisis data pada Perancangan pengembangan wilayah Lembah Harau Kabupaten Lima Puluh Kota dengan strategi Destination Branding, yaitu.

a. Strengths (kekuatan) adalah mengenai kelebihan-kelebihan yang dimiliki oleh suatu produk atau jasa yang akan digunakan sebagai objek permasalahan, dalam hal ini yaitu kelebihan-kelebihan yang dimiliki oleh Lembah Harau.

b. Weakness (kelemahan) adalah segala hal yang menyangkut tentang kekurangan dan kelemahan dari Lembah Harau. 
c. Opportunities (peluang).

d. Threats (ancaman) adalah segala hal yang sekiranya dapat menghambat perkembangan dari Lembah Harau.

\section{HASIL DAN PEMBAHASAN Kajian Teori}

Menurut Ike Janita Dewi (2010:39), mengatakan brand merupakan sebuah penanda yang mengidentifikasikan sebuah perusahaan, produk, jasa, dan tempat dengan menggunkan symbol yang unik demi membedakannya dengan produk serupa dipasaran. Brand berperan sebagai identifikasi suatu produk. Brand memiliki manfaat bagi konsumen untuk membedakannya dengan produk lainnya. Sehingga brand dapat didefinisikan sebagai sebuah identitas, janji, ide besar, dan harapan sebuah product, service atau perusahaan, jasa, dan tempat yang membedakannya dengan yang lainnya.

Sedangkan menurut Rustan (dalam 2013:16), branding merupakan suatu kegiatan yang bertujuan untuk membangun sebuah brand salah satu contohnya pembuatan sebuah logo. Brand dan branding merupakan istilah yang memiliki pengertian yang berbeda. Branding dapat digunakan sebagai istilah suatu kegiatan pemberian nama merek, citra merek suatu produk. Branding juga dapat diartikan sebagai serangkaian proses dan aktivitas untuk menciptakan suatu brand.

Berdasarkan pengertian brand dan branding di atas, Destination Branding dapat diartikan sebagai strategi dari suatu destinasi wisata untuk membuat positioning (selalu diingat, mudah diingat, dan memiliki tempat tersendiri) yang kuat di benak wisatawan terhadap objek pariwisata tersebut. Strategi branding memiliki kemampuan untuk menghasilkan citra atau kepribadian yang unik sehingga mampu mendiferensikan sebuah destination wisata dari destination-destination wisata lainnya. Strategi destination branding diperlukan oleh objek wisata Lembah Harau untuk membentuk image dan positioning yang kuat di benak wisatawan sebagai kawasan ekowisata. Perancangan ini diharapkan mampu meningkatkan kesadaran masyarakat untuk menjaga keseimbangan lingkungan dan alam wilayah Lembah Harau.

Perancangan Destination Branding Lembah Harau memiliki tujuan untuk membentuk karakter identitas wilayah Lembah Harau sebagai kawasan ekowisata yang bertanggung jawab terhadap alam dan lingkungan. Sebagai kawasan ekowisata, Lembah Harau dapat dikenal sebagai tempat yang unik dan menarik yang dapat memberikan gambaran dari pikiran, perasaan, asosiasi dan ekspektasi bahwa Lembah Harau sebagai tempat yang indah dan nyaman dijadikan tujuan wisata. Destination branding Lembah Harau juga berpeluang besar untuk meningkatnya angka kunjungan wisatawan (lokal dan mancanegara) yang datang ke Objek Wisata Lembah Harau. Selain itu, destination branding Lembah Harau juga bertujuan untuk memberikan kesadaran bagi masyarakat setempat dan wisatawan untuk ikut berpartisipasi menjaga keseimbangan alam dan lingkungan wilayah Lembah Harau.

Perancangan Destination Branding Lembah Harau sebagai kawasan Ekowisata terdiri dari 4 (empat) bagian tahapan metode penciptaan, yaitu metode pengumpulan data, metode analisis data, kajian konsep, dan visualisasi perancangan. Metode pengumpulan data merupakan tahapan awal untuk memulai perancangan. Pengumpulan data bertujuan untuk memperoleh data yang tepat dan benar sehingga memudahkan perancangan. Data yang diperoleh berupa data premier dan data sekunder.

Setelah melakukan metode pengumpulan data, data yang diperoleh dalam proses pengumpulan data akan dianalisis dan dikelompokkan. Penganalisisan data bertujuan untuk 
mengelompokkan data sesuai dengan kebutuhan sehingga data yang kurang tepat akan tersingkir. Data-data yang telah dianalisis akan memudahkan proses perancangan untuk menentukan kelebihan dan kekurangan dari Wilayah Lembah Harau sesuai fakta yang ada. Metode analisis data yang dilakukan terdiri dari 2 (dua), yaitu analisis deskriptif dan analisis SWOT.

Menurut Tim Wesfix (2017:32), seluruh proses riset, mengarah pada pemahaman akan kebutuhan yang berkaitan dengan brand yang sedang dibangun. Rekomendasi yang baik dihasilkan dari proses analisis dengan data yang akurat, membuahkan strategi cemerlang. Setelah menganalisisan data dilakukan, data-data yang didapat dari hasil analisis digunakan untuk merangkum konsep perancangan. Hasil dari analisis data di gambarkan pada proses brainstorming untuk mendapatkan konsep perancangan yang lebih jelas. Konsep perancangan digunakan dalam perancangan Destination Branding Lembah Harau. Konsep terdiri dari 2 (dua), yaitu konsep visual dan konsep verbal. Konsep ini akan digunakan pada tahapan perancangan mulai dari Brand Identity hingga Brand Communication.

Setelah melakukan kajian konsep perancangan tahapan selanjutnya adalah visualisasi perancangan. Visualisasi perancangan terdiri dari sketsa desain, alternatif visual, dan desain komperhensif. Tahapan ini merupakan akhir dari perancangan yang menghasilkan rancangan final.

\section{Konsep umum}

Konsep yang digunakan pada perancangan Destination Branding Lembah Harau secara umumnya adalah konsep ekowisata. Lembah Harau sebagai kawasan pelestarian alam memerlukan kegiatan yang dapat menjaga keseimbangan antara aspek ekonomi dan aspek lingkungan yang mencangkup ilmu pengetahuan, penelitian, pendidikan, budidaya, budaya, dan sosial masyarakat. Hal ini yang menjadikan konsep ekowisata sesuai dengan wilayah Lembah Harau sebagai kawasan pelestarian alam. Perlu adanya peran partisipasi dari masyarakat Lembah Harau dan pengunjung untuk keseimbangan alam dan lingkungan wilayah Lembah Harau. Semua ini tergambar pada konsep ekowisata perancangan Destination Branding wilayah Lembah Harau.

Brand wilayah Lembah Harau akan memberikan cap identitas bahwa wilayah ini mengusung konsep ekowisata. Image yang diberikan akan memberikan positioning dibenak target audient bahwa wilayah Lembah Harau merupakan objek wisata yang mengusung konsep ekowisata yang peduli akan keseimbangan alam dan lingkungan di samping mementingkan potensi estetika yang ada. Konsep Ekowisata akan tergambar pada nama wilayah Lembah Harau berupa Brand Identity dan Brand Communication pada perancangan Destination Branding Wilayah Lembah Harau.

\section{Konsep Verbal}

Bentuk verbal yang akan dirancang tentu menggunakan konsep ekowisata. Perancangan brand name (nama Brand) pada Destination Branding Lembah Harau mencerminkan keseimbangan aspek ekonomi dan aspek lingkungan sehingga Lembah Harau akan dikenal sebagai objek wisata yang mengusung konsep ekowisata. Nama brand nantinya berkaitan dengan nama-nama yang bersifat lingkungan dan alam.

Perancangan brand name Lembah Harau bertujuan untuk memberikan image sebagai kawasan ekowisata. Selain itu brand name yang lebih sederhana dan menarik serta unik dapat menjadi positioning yang kuat dalam benak wisatawan. Perancangan brand name menggunakan bahasa Inggris bertujuan untuk membawa objek wisata Lembah Harau lebih mendunia. Harau 
Valley dipilih sebagai brand name yang memiliki arti Lembah Harau. Nama Harau Valley sudah mulai dikenal orang karena wisatawan asing mengal Lembah Harau dengan Harau Valley. Brand name yang mudah diucapkan dan mudah dibaca menggunakan bahasa internasional memudahkan wisatawan mancanegara mengingat brand name Lembah Harau. Brand name yang menggunakan bahasa Inggris diharapkan mampu meningkatkan wisatawan mancanegara objek wisata Lembah Harau.

Brand name Harau Valley akan digunakan pada letter marks (bagian tulisan pada logo). Selain brand name, letter mark pada logo dilengkapi kata-kata of Lima Puluh Kota dibagian bawah brand name. Kata-kata of Lima Puluh Kota berperan sebagai informasi bahwa Lembah Harau memiliki brand name baru dengan nama yang berbeda dari yang biasa masyarakat dan wisatawan dengar untuk wisata Lembah Harau yang terdapat di Kabupaten Lima Puluh Kota.

Tag line untuk destination branding Lembah Harau sebagai kawasan Ekowisata ini adalah Enjoy the Beauty. Sesuai artinya nikmatilah keindahannya, wisata Lembah Harau memiliki keindahan alam yang asri untuk dinikmati. Sehingga tagline Enjoy the Beauty memiliki makna untuk mengajak wisatawan datang untuk berbahagia dan merasa nyaman menikmati keindahan alam, keindahan lingkungan, dan keindahan karifan lokal Wilayah Lembah Harau.

\section{Konsep Visual}

Elemen-elemen visual pada perancangan visual Destination Branding terinspirasi dari keindahan alam Lembah Harau. Hal ini dapat terlihat dari pola bentuk tebing yang merupakan spot yang paling disukai pengunjung pada Lembah Harau. Spot ini paling disukai pengunjung karena keindahannya. Penulis menyebut spot ini memiliki proporsi Golden Ratio atau nama lainnya yaitu Golden Section.
Menurut Yongki Safanayong (2006:39-40), Golden Section dapat dilihat dari bentuk alami lingkungan dan alam semesta, baik itu disengaja atau pun tidak disengaja yang menciptakan visual yang secara psikologis menyenangkan ketika dilihat oleh mata. Prinsip Golden Section sesuai dengan konsep Ekowisata yang tetap menjaga keseimbangan alam disamping diperolehnya upaya pengembangan potensi estetika yang ada. Golden Section ini menjadi big idea bagi pengkarya dalam konsep visual perancangan Destination Branding wilayah Lembah Harau sebagai kawasan Ekowisata. Sesuai dengan maknanya big idea adalah konsep besar yang bagus sehingga Golden Section merupakan point penting dalam perancangan ini.

Spot yang memenuhi persepsi Golden Section di wilayah Lembah Harau adalah spot dua buah bukit yang dari tahun 1986 hingga sekarang masih sama keindahannya. Spot tersebut sudah terkenal keindahannya diingatan wisatawan memberikan keuntungan jika diaplikasikan pada visual identity yaitu logo. Wisatawan akan langsung mengenali visual identity Lembah Harau dengan melihat sekali saja. Penggunaan spot memudahkan wisatawan mengingat dengan jelas keindahan spot tersebut di Lembah Harau.

Penggabungan Titik Golden Section dan pola guratan pada tebing di Lembah Harau merupakan Big Idea pembentukan logo. Pola bentuk ini disatukan dan disederhanakan sehingga terbentuk menjadi pola yang mudah diingat. Tentunya diperlukan riset lanjutan dan alternatif pola demi mendapatkan pola bentuk yang memiliki positioning yang kuat.

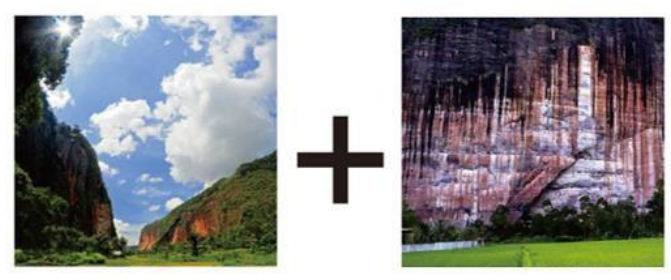




\section{Gambar 1 : Pola bentuk bukit dan pola guratan pada tebing sebagai big idea Picture Mark logo \\ Sumber : Rini Amadi}

Setelah ditentukan big idea dari perancangan brand identity yaitu Logo, diperlukan beberapa sketsa alternatif yang menggambarkan big idea. Pola-pola yang ada pada big idea dikembangkan membentuk satu kesatuan pola yang baru. Pola gambar yang baru ini akan digunakan pada Picture Mark (Bagian logo yang berbentuk gambar) di dalam logo.

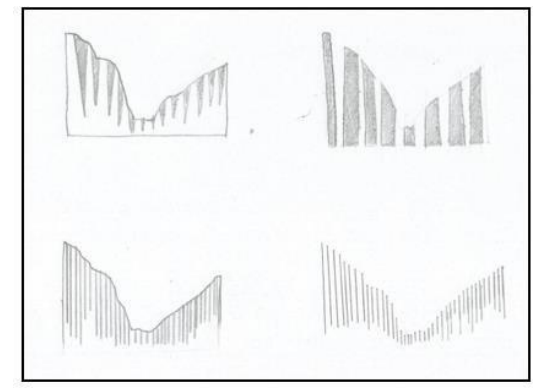

\section{Gambar 2 : Sketsa Picture Mark logo Sumber : Rini Amadia}

Setelah pembuatan pola Picture Mark pada logo diperlukan tagline atau yang disebut dengan Letter Mark (Bagian logo yang berbentuk tulisan) untuk memperkuat Picture Mark (Bagian logo yang berbentuk gambar) yang telah ada. Letter mark merupakan nama identitas dari wilayah Lembah Harau. Tahap berikutnya adalah pemberian warna yang tepat sesuai dengan makna dari warna dan konsep ekowisata.

Menurut Andi Kusrianto (2007:47), secara visual warna memiliki kekuatan yang mampu mempengaruhi citra orang yang melihatnya. Elemen-elemen warna yang natural yang biasa ada di alam memberikan kesan yang lebih dekat dengan alam dan lingkungan, seperti warna coklat, abu-abu, biru muda, dan hijau sehingga memberikan kesan keseimbangan alam dan lingkungan. Warna-warna yang digunakan akan mencerminkan makna dari warna itu sendiri. Warna-warna ini akan terlihat pada visual identity $(\log 0)$ dan beberapa media visual grafis pendukung.
Setelah itu diperlukan perancangan elemen-elemen grafis yang sesuai dengan konsep Ekowisata dan persepsi Golden Section yang nantinya akan digunakan pada Corporate Identity dan Brand Comunication. Corporate identity merupakan bentuk visual identitas yang menggambarkan brand dalam berbagai media. Brand communication merupakan strategi untuk berkomunikasi dengan target audien. Brand communication terdiri dari brand visualization yang digunakan sebagai brand activation. Brand activation berfungsi sebagai pengenalan brand identity kepada target audien

Konsep perancangan brand activation untuk brand Harau Valley terinspirasi dari tingkah laku dan kebiasaan target audient dalam melakukan aktifitas sehari-hari. Alat transportasi massal masih menjadi pilihan bagi masyarakat yang ingin berpergian dengan jarak yang jauh yaitu pesawat, kereta api, dan bus. Semua kalangan dan umur pernah menggunakan alat transportasi massal. Biasanya pada alat transportasi massal memiliki tempat tunggu atau ruang tunggu untuk jadwal keberangkatan yaitu di bandara, di stasiun, dan halte. Kadangkala waktu yang dihabiskan orang-orang untuk menunggu jadwal keberangkatan mereka memakan waktu yang lama sehingga mereka memilih melakukan kegiatan lain. Bermain smartphone merupakan pilihan mereka untuk menghabiskan waktu untuk menunggu. Pengkarya menjadi terinspirasi melihat situasi ini untuk menjadikannya sebagai konsep brand activation brand Harau Valley.

Pengkarya merancang sebuah brand activation dengan penempatannya di area ruang tunggu yaitu di halte, stasiun, dan bandara. Konsep yang digunakan adalah pop-up background yang akan diaplikasikan pada dinding area tempat duduk halte dan ruang tunggu. Background ruang tunggu adalah spot bukit golden section yang ada di Lembah Harau. Background ini dibuat 
dengan beberapa layer yang memiliki pola bentuk seperti spot bukit golden section tersebut. Target audient yang sedang menunggu transportasi massal akan menunggu di ruang tunggu yang telah dirancang tersebut. Background dengan konsep pop-up ini akan memberikan sensasi 3D bukit yang ada pada background sehingga memberikan ilusi sedang berada di dekat bukit tersebut. Selama menunggu target audien dapat mengunjungi website harau valley yang alamat webnya terdapat pada salah satu sisi dari brand activation.

\section{Final Logo}

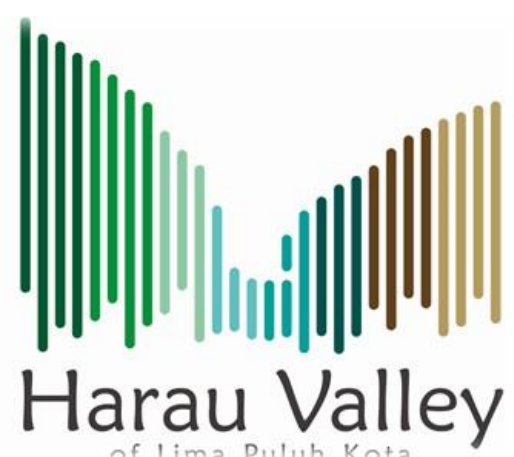

\section{Gambar 4 : Final Logo Lembah Harau Sumber : Rini Amadia}

Logo Lembah Harau, terdiri dari lettermark dan picture mark. Letter mark diambil dari brand name yang telah dikonsep yaitu Harau Valley. Di bawah leter mark terdapat kalimat of Lima Puluh Kota yang merupakan penjelasan bahwa Harau Valley terdapat di Lima Puluh Kota. Huruf yang digunakan pada letter mark adalah huruf Candara. Huruf Candara merupakan huruf yang sederhana, mudah dibaca, dan unik. Dikatakan unik karena terdapat serif (anatomi kaki pada huruf) yang tidak kaku dan tidak terlalu lebar. Pemilihan huruf Candara pada letter mark yang simple bertujuan sebagai penyeimbang picture mark pada logo yang sudah memiliki banyak pola dan warna.

\section{Pengaplikasian logo}

Pengaplikasian logo Harau Valley berupa perancangan corporate identity dan brand communication. Pengaplikasian logo Harau Valley dirancang berdasarkan ketentuan penempatan logo, warna, font, dan elemen grafis yang telah ditetapkan sebelumnya. Corporate identity Harau Valley (Lembah Harau) terdiri dari kategori stasionary, souvenir, seragam, kendaraan, media sosial, dan grafis lingkungan. Kategori yang dipilih disesuaikan dengan keterbutuhan pemakaiannya. Brand communication terdiri dari visualisasi brand activation. Brand Activation berupa desain ruang tunggu di bandara dan halte.

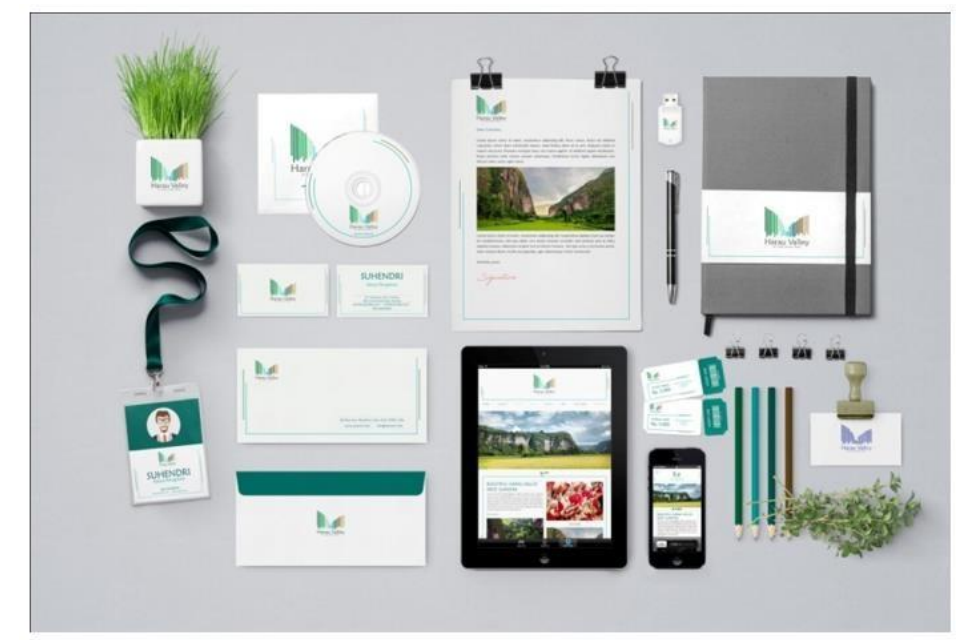

Gambar 5 : Stasionary Harau Valley Sumber : Rini Amadia 


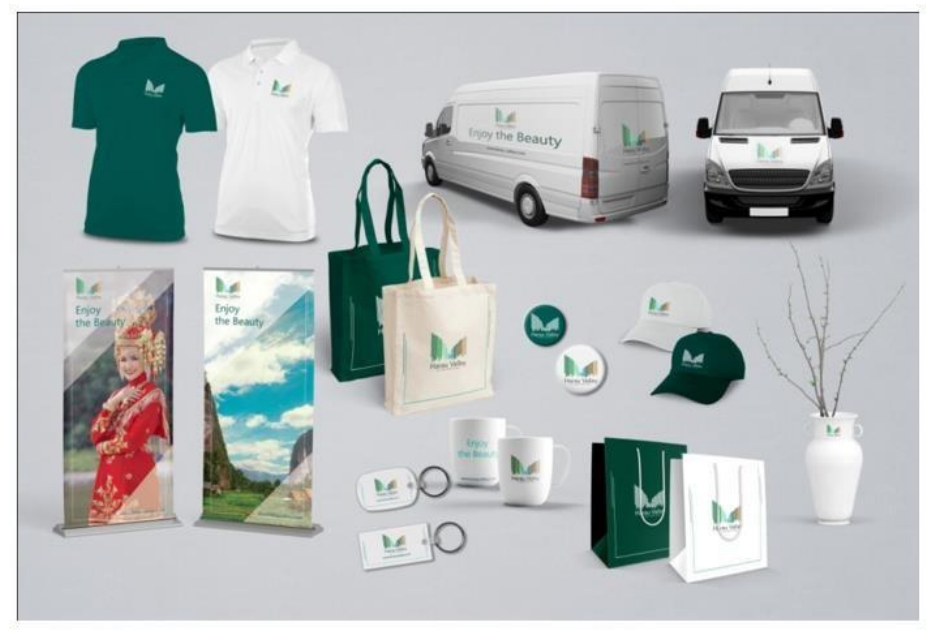

Gambar 6 : Souvenir, seragam, mobil, banner Harau Valley Sumber : Rini Amadia

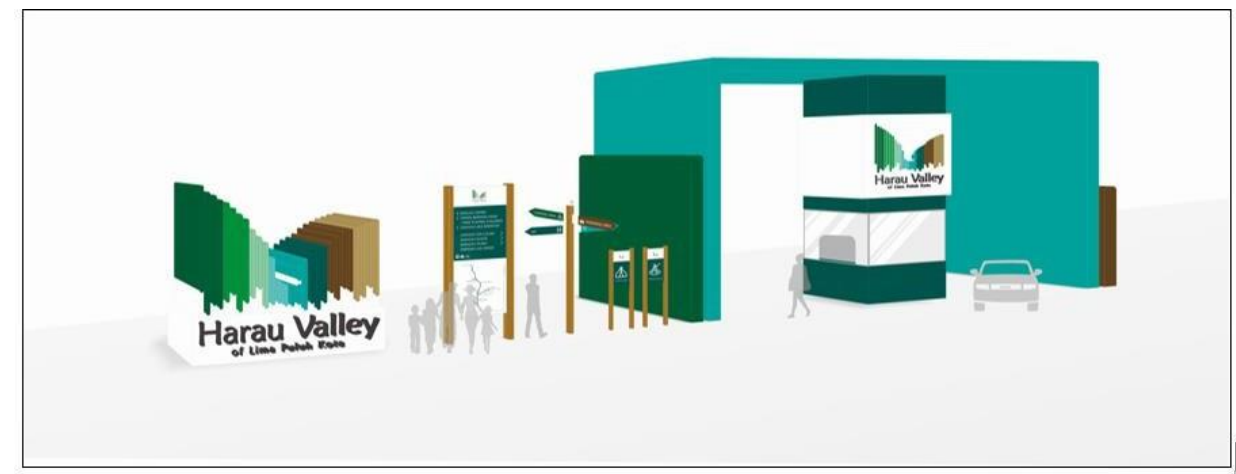

Gambar 7 : Media grafis lingkungan Harau Valley Sumber : Rini Amadia

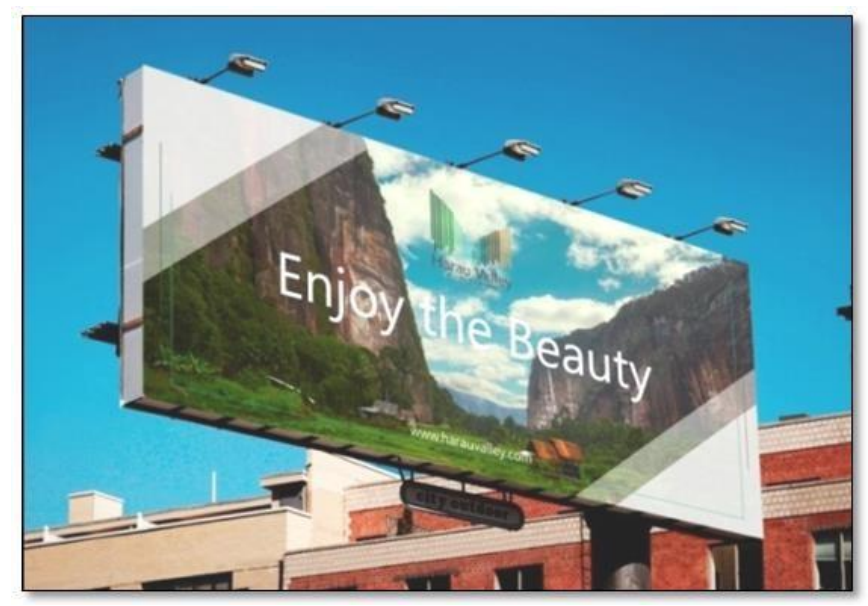

Gambar 8 : Desain Baliho Brand Harau Valley Sumber : Rini Amadia 


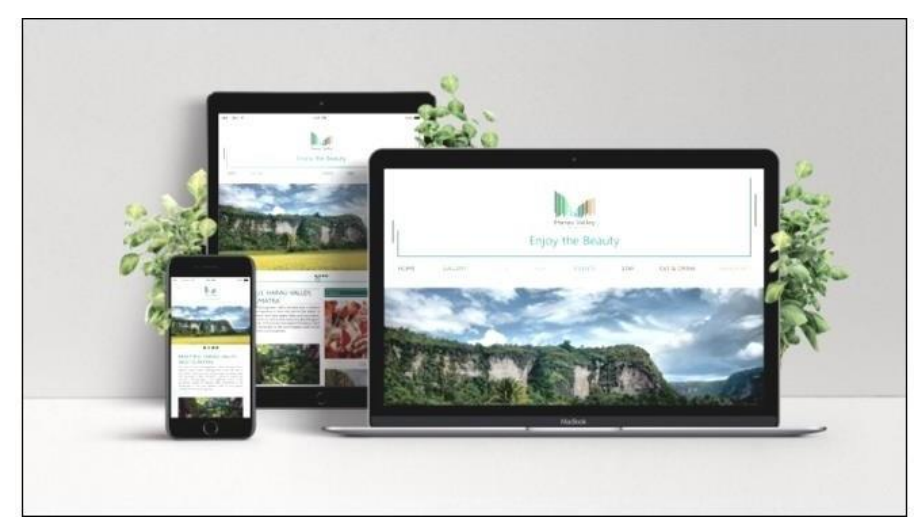

Gambar 9: Desain Banner Brand Harau Valley Sumber : Rini Amadia

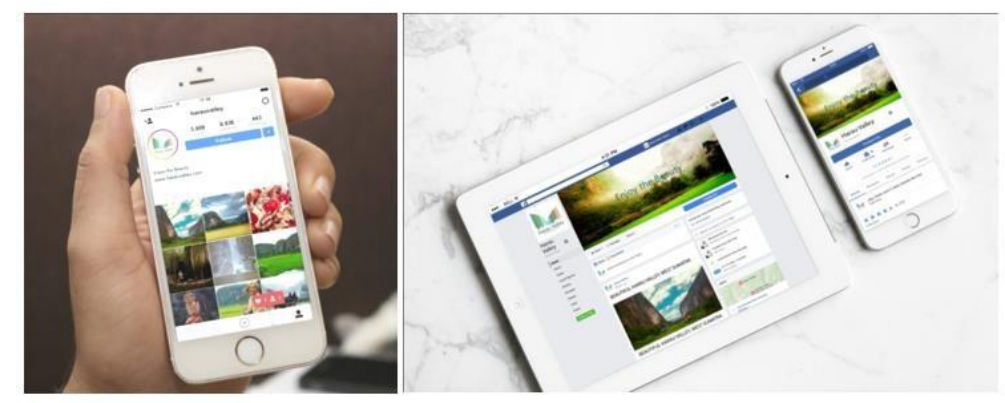

Gambar 10 : Tampilan Akun Instagram dan facebook Brand Harau Valley Sumber : Rini Amadia

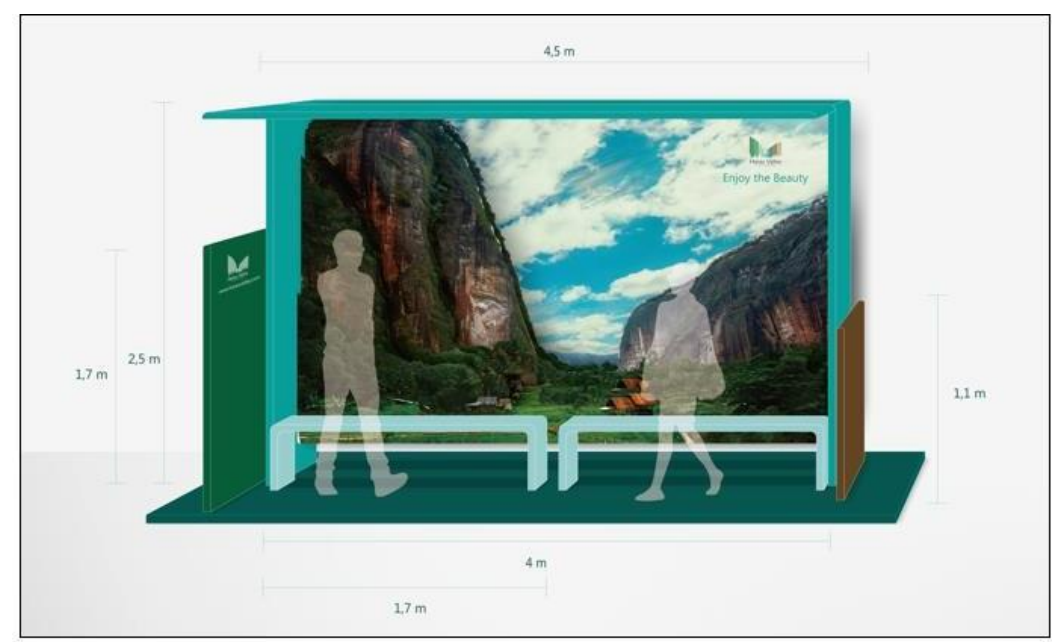

Gambar 11 : Ukuran Brand Activation

Harau Valley di Halte Bus

Sumber : Rini Amadia 


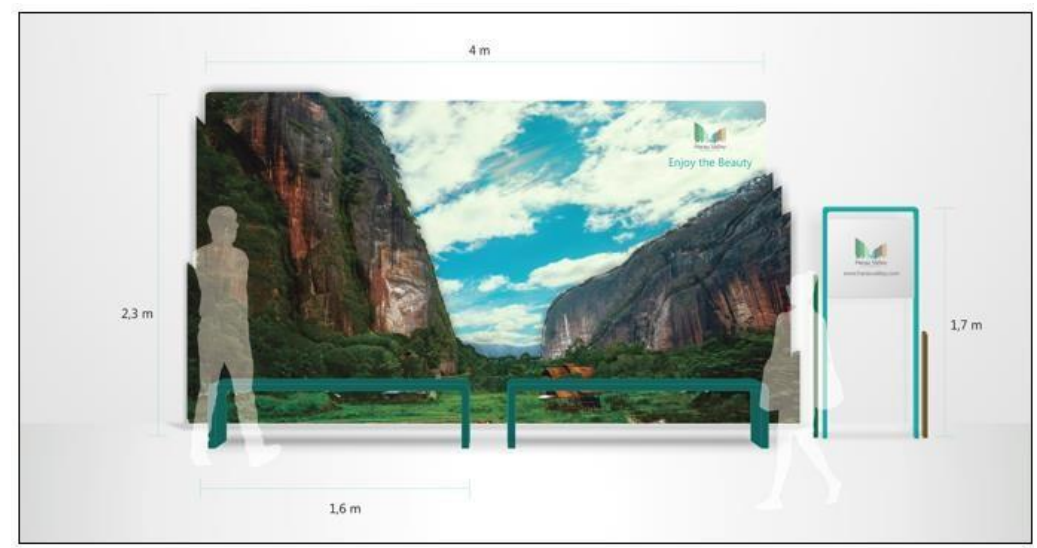

Gambar 12 : Ukuran Brand Activation Harau Valley di Ruang Tunggu Bandara dan Stasiun Sumber : Rini Amadia

\section{SIMPULAN}

Sebuah brand pariwisata merupakan kegiatan yang dapat menunjang perkembangan pariwista. Brand perlu dijadikan perhatian oleh berbagai pihak karena brand dapat mengubah persepsi masyarakat akan citra dan image suatu wilayah atau objek wisata menjadi lebih baik. Destination Branding merupakan strategi untuk penciptaan image atau identitas bagi suatu daerah/kawasan dengan cara membuat positioning tersendiri. Image yang diciptakan pada peracangan destination branding objek wisata Lembah Harau adalah sebagai kawasan ekowisata yang sejalan dengan prinsip kawasan pelestarian alam. Image ini perlu diperkenalkan supaya dalam pengaplikasiannya dapat saling bekerjasama dalam menjaga kelestarian alam sesuai dengan prinsip kawasan pelestarian alam.

Melalui destination branding Lembah Harau sebagai kawasan ekowisata diharapkan memiliki fungsi kepercayaan (awareness) sebagai kawasan yang mementingkan kelestarian alam dan lingkungan serta kearifan lokal yang dimiliki. Selain itu diharapkan perancangan ini mampu memberikan gambaran dari pikiran, perasaan, asosiasi dan ekspektasi bahwa Lembah Harau sebagai tempat yang indah dan nyaman dijadikan tujuan wisata. Keberhasilan destination branding Lembah Harau dapat memberikan keuntungan bagi wilayah itu sediri dari aspek pemeliharaan lingkungan dan alam serta ekonomi.

Perancangan destination branding Lembah Harau sebagai kawasan Ekowisata yang telah dilakukan merupakan perancangan meliputi brand identity dan brand communication. Disarankan untuk melakukan perancangan lebih terhadap brand communication khususnya brand activation. Diperlukan perubahan brand activation sesuai dengan perkembangan zaman. Perubahan ini bertujuan supaya target audient yang dituju sesuai dengan perkembangan zaman dan tren.

\section{UCAPAN TERIMAKASIH}

Puji Syukur penulis ucapkan kepada Allah SWT memberikan kemudahan dalam penelitian dan penciptaan karya ini. Terimakasih kepada Pemda daerah Lima Puluh Kota dan Dinas Pariwisata Lima Puluh Kota dalam membantu menyelesaikan riset dan analisis yang penulis lakukan. Serta ucapan terimakasih kepada berbagai pihak dalam membantu memundahkan penulis menyelesaikan penelitian dan penciptaan karya ini

\section{DAFTAR PUSTAKA}


Danmanik, Janianton \& Helmut F.Weber. 2006.Perencanaan Ekowisata dari Teori ke Aplikasi. Penerbit Andi : Yogyakarta.

Dewi, Ike Janita. 2010. Implementasi dan Implikasi Kelembagaan Pemasaran Pariwisata yang Bertanggung Jawab (Responsible Tourism Marketing). Penerbit Pinus Book : Kementrian Kebudayaan dan Pariwisata Rebuplik Indonesia

Ismet, Yogi. 2011. Konsep Pengembangan Lanskap Berbasis Ekowisata di Kawasan Taman Wisata Alam Lembah Harau, Sumatera Barat. Departemen Arsitektur Lanskap Fakultas Pertanian Institut Pertanian Bogor .Bogor

Rustan, Surianto. 2013. Mendesain Logo. Gramedia : Jakarta.

Kanesti, Novita. 2008. Pengembangan Pariwisata Alam Prioritas Di kabupaten Lima Puluh Kota Propinsi Sumatera Barat.
Departemen Konservasi Sumberdaya Hutan dan Ekowisata Fakultas Kehutanan Institut Pertanian Bogor. Bogor

Katalog BPS. 2015. Lima Puluh Kota dalam Angka.Badan Pusat Statistik. Lima Puluh Kota.

Kusrianto, Adi. 2007. Pengantar Desain Komunikasi Visual. Penerbit Andi : Yogyakarta.

Safanayong, Yongky. 2006. Desain Komunikasi Visual Terpadu. Arte Intermedia : Jakarta.

Undang-Undang Republik Indonesia Nomor 5 Tahun 1990 Tentang Konservasi Sumber Daya Alam Hayati dan Ekosistemnya. Lembaran Negara Republik Indonesia Tahun 1990 Nomor 49. Tambahan Lembaran Negara Republik Indonesia Nomor 3419.Sekretariat Negara : Jakarta.

Wesfix, Tim. 2017. Branding Itu Dipraktekin. Penerbit Grasindo : Jakarta 